\title{
Note from the SBIC President
}

(C) SBIC 2014

\section{The Society of \\ Biological Inorganic Chemistry}

SBIC has been established as a learned society of advanced research and education in the field of Biological Inorganic Chemistry

\begin{tabular}{|c|c|c|}
\hline \multicolumn{3}{|l|}{ SBIC COUNCIL } \\
\hline President & Members & Chief Editor of JBIC \\
\hline Masao Ikeda-Saito, Tokyo, Japan & $\begin{array}{l}\text { Norah Barba-Behrens, Mexico City, Mexico } \\
\text { Kara Bren, Rochester NY, USA }\end{array}$ & Lawrence Que Jr., Minneapolis, MN, USA \\
\hline $\begin{array}{l}\text { Past Presidents } \\
\text { José Moura, Lisbon, Portugal }\end{array}$ & Katherine Franz, Durham NC, USA & $\begin{array}{l}\text { Program Committee/ICBIC-IOC } \\
\text { Kenneth D. Karlin, Baltimore, MD, USA }\end{array}$ \\
\hline $\begin{array}{l}\text { Alison Butler, Santa Barbara, CA, USA } \\
\text { Secretary }\end{array}$ & $\begin{array}{l}\text { Michael J. Hannon, Birmingham, UK } \\
\text { Carston Krebs, University Park, PA, USA }\end{array}$ & Nominations Committe \\
\hline Wonwoo Nam, Scoul, Korea & $\begin{array}{l}\text { Shinobu Itoh, Osaka, Japan } \\
\text { Nils Metzler-Nolte, Bochum, Germany }\end{array}$ & $\begin{array}{l}\text { Rachel Codd, Sydney, Australia } \\
\text { SBIC Website: }\end{array}$ \\
\hline $\begin{array}{l}\text { Treasurer } \\
\text { Graeme Hanson, St. Lucia, Australia }\end{array}$ & $\begin{array}{l}\text { Amy Rosenzweig, Evanston, IL, USA } \\
\text { Roland Sigel, Zürich, Switzerland }\end{array}$ & http://SBIChem.org \\
\hline
\end{tabular}

Dear SBIC members and all readers of JBIC:

I am honored to assume the role of the President of SBIC following the former SBIC Presidents, from C. David Garner to Elizabeth C. Theil, Alfred X. Trautwein, Harry Gray, Fraser Armstrong, Bob Scott, Trevor Hambley, José Moura, and Alison Butler. I look forward to working with Wonwoo Nam, the Secretary of SBIC, and Graeme Hanson, the Treasure of SBIC, the SBIC Council, Alison, the immediate Past President, and with all of you. Big thanks to Alison for her leadership during the past two years and for providing me a wonderful guidance the past year. I enthusiastically welcome Kara Bren and Carsten Krebs, the two newly elected SBIC Council members, and Zijian Guo, a newly constituted SBIC Council member. I would like to thank the two outgoing SBIC Council members, Alejandro Vila and Stephen Ragsdale, for their service and advice, all of which was highly appreciated.

We just had a highly successful EuroBIC-12 in Zürich co-chaired by Eva Freisinger and Roland K. O. Sigel (both of Universität Zürich) between August 24 and 28. Congratulations to Xile Hu of Ecole Polytechnique Fédérate de Lausanne for 2014 EuroBIC Medal awarded for his excellent work on [Fe]-hydrogenase model chemistry. During the EuroBIC-12 meeting, the SBIC Council and the SBIC
General Assembly met. Graeme Hanson, our trusted SBIC Treasurer, informs us that SBIC has been financially secure. Thank you to all of you who renewed your SBIC memberships. Welcome to the more than 100 new members who have signed up at EuroBIC-12. Keep recommending SBIC membership to your colleagues and students; SBIC membership benefits are our friendly and collaborative global community and the exceptional international conferences.

AsBIC-17 (http://www.asbic7.org) is approaching, as it will meet between November 30 and December 4 at Gold Coast, Australia, co-chaired by Sue Berners-Price (Griffith University) and Graeme Hanson (University of Queensland). Jim Mayer and Joanne Stubbe have organized an outstanding program for the Metals in Biology, Gordon Research Conference (http:// www.grc.org/programs.aspx?id=11620) between January 25 and 30, 2015 in Ventura, California. ICBIC-17 will meet in Beijing, China between July 20 and 25, 2015. Its website (http://icbic17.org/page.asp?id=B2B87E68A3550AA4C58D46 $5235 \mathrm{BC} 4878$ ) is being prepared and please update yourself by visiting the site for further details.

Yours truly, Masao Ikeda-Saito 